\title{
Colorado University's Divisional Reading Room Plan: Description and Evaluation
}

\section{R. E. Ellsworth is director of libraries at the University of Colorado.}

A NALYsis of the literature of university I library planning will show that the enthusiastic articles usually published at the time of dedication seldom contain a sequel which justifies or disproves the fine claims of the original statement. Whether this is so because there is nothing to say or because we librarians are unable or unwilling to discuss our errors is difficult to tell.

The same analysis will show that the numerous articles written have a great deal to say about styles of architecture, equipment and furniture, new tricks and gadgets, but very little about how all these are to contribute to the educational programs of their university communities. It seems almost as though everyone had come to accept the traditional setup of a building as inevitable, with differences of opinion possible only in terms of relative emphasis. One need only read Munthe's and Branscomb's well-known books published last year, or talk with some of the

1 This plan was derived from many sources: the faculty of the University of Chicago Graduate Li. brary School; from several public libraries organized on the same basis, especially the Enoch Pratt Library; and from several university libraries. Strangely enough Brown University and the University of Colorado have used the same plan, each
one apparently unaware that the other was doing so. more critically minded members of the profession to discover that our library buildings have fostered an attitude toward studying that leaves much to be desiredif one's own observations and thinking have not already done that.

One obligation which Westerners take seriously is their responsibility for experimenting. In terms of college architecture, two factors work in our favor: first, our buildings are usually paid for from taxes, not from wealthy donors; second, we are so isolated and so ignorant, relatively, that the heavy hand of tradition serves only to wave over our heads, creating a refreshing breeze.

The splendid example set by the University of New Mexico in adapting the native Indian Pueblo architecture to their new library building is noteworthy, while the Colorado State College of Education has demonstrated a new and interesting method of bringing the instructional program of the college into the library. We hope that the University of Colorado, too, will have made a contribution by showing what the subject divisional plan can accomplish in a university library.

Architecturally speaking, the new library, dedicated last June, but opened for service January 5, 1940, follows the campus style developed by Mr. C. Z. Klauder 
for the university. ${ }^{2}$ It complements the nearby Rockies with their jagged upturned strata of sandstone, their pungent harmony of line, mass, and color, their crude jumbledness and their almost overbearing massiveness. The campus buildings are constructed of local sandstone, each stone a slightly different combination of brown, red, and purple, which in mass tend to make the buildings become a part of their surroundings.

The building cost $\$ 500,000$ with $\$ 40,000$ added for equipment. It contains a million and one-half cubic feet of space, it will seat about sixteen hundred students, and will house over a million volumes. It can be expanded to double its present size. The interior achieves its effectiveness through simplicity of design, material, and decoration. Fluorescent lighting is used in all the reading rooms and some day will be installed in all smaller rooms. The tables, chairs, and reading-room shelving were designed specifically for the building. A system of ventilation created especially for our dry climate enables us to keep the readingroom temperatures in the middle seventies even during the hottest part of the summer-which is much appreciated by our summer school students who come from the Middle West and the South.

So much for the structure, which is interesting and unique, but not so important as the educational plan.

\section{A Working Program}

In the first issue of College and $R e$ search Libraries, December, 1939, I presented the hypotheses underlying the plan. The building has been in operation since January, I940, and these hypotheses

${ }^{2}$ See cuts in the December, 1939, number of $\mathrm{Col}$ lege and Research Libraries. may therefore now be stated and discussed in terms of a working program.

Four divisional reading rooms form the nucleus of the service. These will be presented as they function for the university community.

First, freshmen and sophomores find assembled for them in the Lower-Division Reading Room a collection of about 8000 books and periodicals which have been carefully selected to meet their needs. This will be developed up to 15,000 volumes. Each department of instruction places here a group of books (reserved books are shelved in with non-reserved books in one single call-number order) which it would like to think of as the common intellectual heritage of all university students, whether they are to be poets or engineers. General and elementary texts, books which have been written to explore whole fields, to establish relationships, or to create a desire for further knowledge in the field represent a few of the types of publications placed in the rooms.

\section{Magazines on Open Shelves}

A small collection of newspapers and magazines like Harpers, Atlantic Month$l y$, the New Yorker, and Life are kept here, and publications on vocational guidance form one group, all on open shelves. Reserved books may be used within the room as long as the reader can stay, and each reader goes directly to the shelves for his books. He asks for help only when he needs it. If the particular book he wants is in use, the chances are good that he will find a substitute from the hundreds of titles on the same subject. The reserved books bring him into the library, but the non-reserved books, which he finds constantly jostling his elbows, lure him 
into further reading. The collection, however, is not too extensive for freshmen to absorb. Comfortable upholstered chairs are there if he cares to stay long hours, or if he wishes to relax a few minutes with the New Yorker.

\section{Homogeneous Reading Group}

Since the lower-divisional reader is surrounded not by awesome faculty members, chosen from a high-school teaching position for her ability to understand and help freshmen bridge the gap between high school and the university. She is not a library technician but a reading adviser. She has to know good library housekeeping principles, but her main task is to help young learners understand the tools and techniques of their craft. She does this both individually and collectively. For

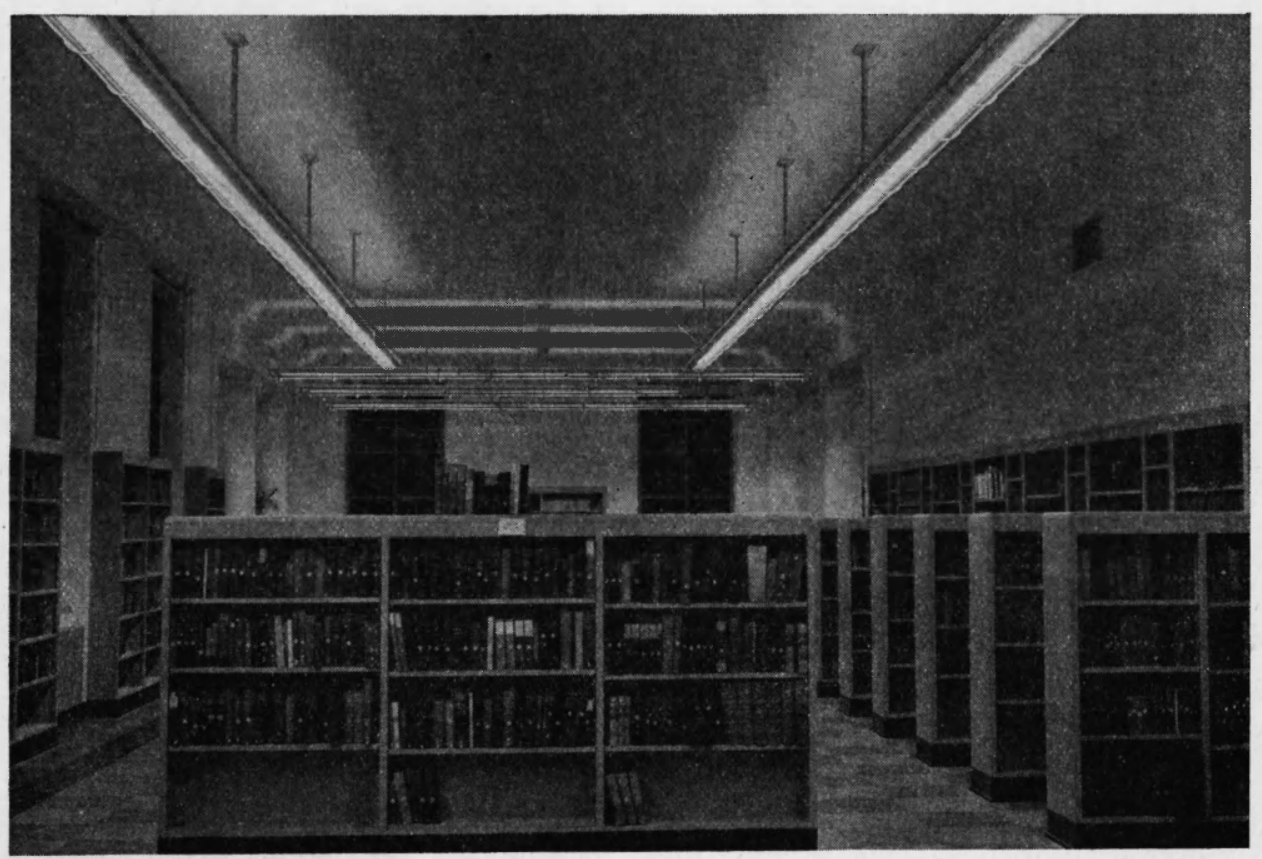

\section{Lower-Divisional Reading Room}

sophisticated and university-wise upper classmen, and finicky graduate students, but by other inexperienced and restless freshmen whose reading problems are like his, the clientele is a homogeneous reading group. He isn't self-conscious about asking questions about things that are obvious to an upper classman but puzzling to a freshman.

The lower-divisional librarian was group instruction she has her office and a conference room, seating fifteen students. For larger groups she uses the Music Room on the top floor. The reading room is L-shaped and is broken up into ten small units by double book shelves placed across the room. (See illustration.) Thus, the librarian, or an instructor, can sit down with a student and discuss his problem without disturbing many other 
readers. The librarian is a teacher and is given professional rank according to her education and experience. Since all four reading rooms are administered similarly, the following description will serve for all of them.

\section{Single Checking Desk}

A checking desk at the single entrance is staffed by student assistants who examine each book taken from the room. Since the checker is a fellow student, not an adult "policeman" to be tricked, students accept his task with easy amicability -and very few books are stolen. When pressure on a particular title becomes too great, it is placed on a small closed reserve section at the checking desk. Thus far, there have never been more than fifty titles at this desk.

When the divisional librarian is not on duty, her place is taken by a graduate student assistant whose special field of interest relates to the contents of the divisional room, and who has served for several years as a student assistant. These people accept their responsibilities seriously and are able to supervise the room and answer many of the questions which come their way. They know when to refer a question to their superior and when to answer it themselves. The training they receive in this work gives them an insight into teaching problems that will add greatly to their repertoire when they become teachers or librarians.

Second, three upper-divisional rooms exist-the Science Room on the main floor, the Social Sciences and the Humanities Rooms on the second floor,--for the upper-divisional and graduate students. Each of these rooms is identical to the lower-divisional room in size, shape, arrangement, and administration. The collections, however, include the more advanced publications which the faculty think will be read most by upper-division students. The collections are selected by faculty members of each department in consultation with the divisional librarians. Reserved books are shelved alongside non-reserved books and the specialized journals and reference books in that field. Current issues of journals are kept in one place within the rooms, with a few comfortable chairs close at hand. A typewriting room is available in each of these rooms so that students may bring their own machines, or rent one if they choosealso a Monroe calculating machine. By this provision we eliminate some of the necessity for charging out periodicals and reference books. Each divisional room opens directly into the stacks and access is open to all. No one can leave the stack room without passing a guard desk.

\section{Five Seminars Available}

Five seminars separate the reading rooms for the humanities and social sciences. These are not reading rooms; they house no permanent collections. Faculty members who wish to conduct a seminar in one of them take to the room the books that are to be used at the time, or may send someone for a book when the need arises. Smoking is permitted in the seminars, and at least one faculty member brews coffee for his Monday evening group.

Each divisional librarian in the upperdivisional rooms has an academic training up to at least the Master's level in one of the subject fields in her particular division. She also has the usual minimum library training, but her technical duties are not extensive. She, like the lowerdivisional librarian, has to know library 
technique, but her most important task is to be a bibliographic adviser to students who have gone through the elementary learning stages, and who are probing about on the frontiers of knowledge.

No one reading room is, of course, large enough to house even a majority of the important books in any one field. Each room includes the books which the faculty thinks will be used most; the rest are kept in the stacks on the same floor level as the reading room concerned. Only four of the possible ten stack floors are now installed, which means that the above principle is not being followed as completely as it will be when the installation is complete.

\section{Cubicles for Graduate Students}

Third, graduate students make their headquarters at cubicles in the stacks or in rooms established on the third floor for that purpose. Part of the material they use will be in the stacks and part in the divisional rooms. All of it, unless reserved, may be taken to the cubicles for as long as it is needed.

Fourth, faculty members engaged upon a specific research project involving library materials have access to faculty studies which become their working space while the project is on. They too, of course, find their publications in the divisional rooms and in the stacks.

Thus, the library can be said to be planned on a subject basis in terms of what might be called the learning or studying levels of the readers. It should be obvious, however, that print and the reader cannot always be fitted into this logical pattern. Thus, several special rooms have been provided.

First, we wished to see if we couldn't make government documents more easily accessible at a smaller cost than they are in libraries where they are cataloged according to subject and shelved with other types of materials. We established a separate Documents Division in which all documents are checked in and shelved according to the Superintendent of Documents classification system, with a supplementary system devised by Mr. Raynard Swank, the documents librarian, for state and local documents. The reading room includes the current and most used material, while the older publications occupy the two bottom floors of the stacks. Documents are not entered in the card catalog except by serial title, nor do they go through the regular acquisition process. Access to them is by way of the document catalogs. Thus, we can afford to handle the many thousands of items which would otherwise swamp the technical processes division.

\section{Browsing Room Maintained}

Second, a browsing room is maintained for those who wish to smoke while they read and who like to roam around among a relatively small collection of new books. The open-shelf divisional plan makes a browsing room less necessary than it is in most libraries, but even so it is desirable.

Third, reference books, periodicals, subject bibliographies, pamphlets, and newspapers which do not belong to any one division are kept in a general reference and bibliography room on the main floor. The room is not large because its clientele is limited.

Fourth, the main circulation desk, that bête noire of graduate students, still exists here but for a different reason. When a book is shelved in one of the reading rooms a guide card is filed in front of the main entry in the catalog and a card is filed in 
the master circulation file. When a student sees this, he goes directly to the indicated room for the book and charges it there. If no guide card is present, he assumes the book is in the stacks and either asks for it at the desk or goes for it himself. The circulation librarian spends little time circulating books (thus far, about eighty books per day), but a great deal helping users of the catalog.

Fifth, the technical processes are located on the main floor with direct access to the receiving room, the stacks, the main card catalog and circulation desk, and the general reference room.

\section{Music Room on Top Floor}

Sixth, a large music room seating up to one hundred and seventy-five people provides a place on the top floor where music can be brought more closely into the instructional program of the university and into the daily lives of the students. Tea is served at the phonograph record concerts which are given daily, and the room is available for concerts and for classes which use music materials. We try to encourage the idea that students should listen to good music as part of their daily study activities.

Seventh, space is provided for a local historical collection on the third floor. Here a librarian sorts, catalogs, and makes available the mass of material which must be organized if a local history collection is to contribute to the culture of the region.

Eighth, a large extension library has been provided on the basement floor, near a film storage room so that the university can, if it wishes, centralize all its visual aid materials into one unified service.

During our eleven months of occupancy we have experienced one full academic cycle, and although this is too short a time upon which to make a final evaluation, certain problems, facts, and relationships have established themselves. A brief discussion of these will serve as a tentative evaluation of the plan.

First, is it possible for each department to select a teaching collection of from three to six thousand volumes, which can be taken from a storage location into an instructional situation? It can be argued that a better plan would be to spread out the stacks, keep all books there and allow free access to them. This might be practical in a college library where the book collection was culled rigorously and where the students were carefully trained in bibliographic methods. But in a large university library the stacks must necessarily contain much that is irrelevant to the student's work and wasteful of his time. Further, most students, certainly freshmen, would flounder and be utterly confused by access to so much material. Our divisional collections contain more than any student can read, and yet they are small enough for undergraduates to work with.

During November 1940, 5869. nonreserved books were circulated from the library. Of these, only 1026 were taken from the stacks; the rest came from the divisional rooms. Inasmuch as we and the faculty have had little to guide us in choosing the reading-room collections, it seems reasonable to assume that we can soon expect, after another year's experience to circulate 90 per cent of the nonreserved books from the various reading rooms. The stacks are thus being restored to their original function-storage.

\section{Number of Reserved Books Cut}

Second, is there any real advantage in abolishing the traditional reserve room 
and intershelving reserved and nonreserved books in a subject-divisional room? This innovation has proven to be the strongest feature of the plan for it has eliminated the noisy confusion and mass production atmosphere of the reserve room and it has caused students to examine and read many books which otherwise would never have been seen. Furthermore, it enables the faculty to cut down on the number of books placed on reserve and makes it possible for us to free that 30 per cent of the reserve collection which librarians have been claiming are never used. The plan also enables the faculty to see in one place an instructional collection for any particular subject, and to consider the stimulating qualities of the collection on the students. This is diffcult to do under the traditional plan except through the medium of the syllabus, which is a poor substitute for direct access to books.

\section{Interrelations among Various Fields}

Third, what happens to those subjects that belong in more than one divisional room? Most of us are aware, of course, of the vast number of interrelations among the various fields of knowledge, and therefore in locating particular titles and collections some very lively discussions have occurred. Although the final decision is sometimes based on arbitrary grounds, we find the process stimulating to faculty and students. The latter, especially, are forced to consider relationships which previously had been mere abstractions to them. For instance, a student in the "Ideas in American Literature" course, will find the pure literature in the Humanities Room, but the supporting books on history, economics, political science, sociology, and education will be found in the Social Science Room, while psychology will be in the Science Room, and certain documents in the Documents Room. The student who sees each of these publications in its proper subject setting and in its relation to American literature can hardly escape thinking about relationships. The small amount of time he "wastes" in hunting his books is probably well spent, for the process itself is educational.

Some fields like journalism, home economics, pharmacy, and public speaking, which do have a professional subject literature of their own but which rely heavily on the older disciplines, present a peculiar problem in that the professional literature can be kept in one place, but the literature of the "parent" disciplines will be located elsewhere. This may annoy those who take professional pride in having all the books they use in one place, but it seems logical to keep the literature of basic disciplines together and let the readers go from one to another.

\section{Quality of Service Improved}

Fourth, how do the supervisory and administrative costs compare with those of other libraries? This is not easy to answer because comparisons are difficult, but if one includes the departmental library costs involved in most universities, the differences are not great. Then, too, the quality of service has to be considered. The service given by the four divisional librarians and the two special librarians is probably much better than that possible under the general reference-reserve room combination, for no one librarian can be expected to serve eight or nine hundred students working in all fields of knowledge as well as can a librarian who is working with two hundred students study-

(Continued on page 192) 
eastern university librarians, for organizing a special division in the Library of Congress to act as a clearing house and advisory agency for all cooperative library undertakings. Such a department might assist in such matters as regional catalogs, surveys of resources, divisions of collecting interests, and cooperative storehouses.

In reply, Archibald MacLeish, Librarian of Congress, expressed the willingness of the Library of Congress to assist in this program, if it is requested by the librarians of the country. Mr. MacLeish stressed the fact, however, that the $\mathrm{Li}$ brary of Congress must have added support for any new ventures, and that the library is decidedly short on top administrative officers. On motion of Harry Miller Lydenberg, the conference voted to approve Mr. Boyd's proposal and to support it in any practical fashion.

\section{Colorado University's Divisional Reading Room Plan}

(Continued from page rog)

ing in one divisional area. Thus far, no one on the campus has complained that too much service of a high quality is given.

It is true that full professional service is not provided fourteen hours a day, but we take the position that eight hours of highly specialized service is better than fourteen hours of average service. We are discovering that the graduate student assistants who have worked several years in the library can handle in a reasonably competent manner the elementary reference questions in their subject fields.

Fifth, what about the problem of discipline in the reading rooms which are broken into small units? Perhaps college students in this area are more mature than is the case elsewhere, but we doubt it. From the first day the new building opened, students have acted as we had assumed they would. No one has to take books to get his assignments done; therefore, few books are lost. The reading rooms are quiet. In other words, provide a scholarly atmosphere and students will act accordingly.
Sixth, what has been the result of breaking up the periodical collection and placing the specialized journals with the rest of the subject literature for each field? In general, readers find that this plan saves them time, because of the ease with which they can go from the books to the journals. A few people, however, miss the general periodical room when they read current issues in several fields. Unless the fields are related, such readers have to go to two or three rooms.

Three other questions will be discussed at a later time: ( I) the advantages and disadvantages of the Science-Divisional Reading Room versus separate departmental libraries; (2) the effect of this plan on the work of the general reference librarian; (3) the advantages and disadvantages of a separate documents librarian.

Summary: this discussion has attempted to describe the divisional-library program of the University of Colorado Library with a tentative and partial evaluation of some aspects of the program. Further aspects will be discussed in the future. 